\title{
RELATIVE NUTRITIVE VALUE OF DIFFERENT FORMS OF MILK
}

\author{
BY DR. S. K. KoN \\ National Institute for Research in Dairying, Univirsity of REading
}

$\mathrm{R}$ ECENT Government pronouncements make it clear that during the forthcoming winter there may not be enough fresh milk to go round in Great Britain, and that priority for this milk will be given to certain classes of the population, such as expectant mothers and infants. Adult consumers will receive as part of their national basic share, in addition to liquid, also some concentrated form of milk. milk products, and with war-time limitations this is an admitted impossibility. The unique value of milk for children, adolescents, pregnant and lactating women is now universally recognized.

With the development of our knowledge of vitamins and of methods for their accurate estimation much work has been done on the effects of commercial processing on the food value of milk, and it may be said broadly that these have proved

COMPosition of DIFFERENT Forms of MILK

\begin{tabular}{|c|c|c|c|c|c|c|c|c|c|c|c|c|c|c|c|c|}
\hline \multirow{3}{*}{ Form of Milk } & \multirow{3}{*}{$\begin{array}{c}\text { Calories } \\
\text { per } \\
1.00 \mathrm{gm} .\end{array}$} & \multicolumn{5}{|c|}{ Grams per $100 \mathrm{gm}$. } & \multicolumn{2}{|c|}{$\begin{array}{l}\text { Vitamin } A^{2} \\
\text { activity }\end{array}$} & \multicolumn{2}{|c|}{ Vitamin $\mathbf{D}^{2}$} & \multicolumn{2}{|c|}{ Vitamin $B_{1}$} & \multicolumn{2}{|c|}{ Riboflavin ${ }^{2}$} & \multicolumn{2}{|c|}{ Vitamin $\mathrm{C}^{3}$} \\
\hline & & & & & & & \multirow[b]{2}{*}{$\begin{array}{c}\text { I. } . . \\
\text { per } \\
100 \mathrm{gm} .\end{array}$} & \multirow{2}{*}{$\begin{array}{c}\text { loss } \\
\text { in } \\
\text { manu- } \\
\text { fac- } \\
\text { ture }\end{array}$} & \multirow{2}{*}{$\begin{array}{c}\text { I.U. } \\
\text { per } \\
100 \mathrm{gm} .\end{array}$} & \multirow{2}{*}{$\begin{array}{c}\text { loss } \\
\text { in } \\
\text { manu- } \\
\text { fac- } \\
\text { ture }\end{array}$} & \multirow{2}{*}{$\begin{array}{c}\text { r.U. } \\
\text { per } \\
100 \mathrm{gm} .\end{array}$} & \multirow{2}{*}{$\begin{array}{c}\text { loss } \\
\text { in } \\
\text { manu- } \\
\text { fac- } \\
\text { ture }\end{array}$} & \multirow{2}{*}{$\begin{array}{l}\text { mgm. } \\
\text { per } \\
100 \mathrm{gm} .\end{array}$} & \multirow{2}{*}{\begin{tabular}{|c|} 
loss \\
in \\
manu- \\
fac- \\
ture
\end{tabular}} & \multirow[b]{2}{*}{$\begin{array}{c}\text { mgm. } \\
\text { per } \\
100 \mathrm{gm} .\end{array}$} & \multirow{2}{*}{$\begin{array}{l}\text { loss } \\
\text { in } \\
\text { manu- } \\
\text { fac- } \\
\text { ture }\end{array}$} \\
\hline & & Water & $\begin{array}{c}\text { Protein } \\
(\mathrm{N} . \times \\
6 \cdot 38)\end{array}$ & Fat & $\begin{array}{l}\text { Carbo- } \\
\text { hydrate }\end{array}$ & $\begin{array}{l}\text { Cal- } \\
\text { cium }\end{array}$ & & & & & & & & & & \\
\hline Raw & 66 & $87 \cdot 6$ & $3 \cdot 3$ & $3 \cdot 6$ & $4 \cdot 7$ & $0 \cdot 120$ & $\overrightarrow{70-200}$ & $\longrightarrow$ & $0 \cdot 5-3 \cdot 0$ & $\longrightarrow$ & 12 & $\ldots$ & $0 \cdot 1-0 \cdot 2$ & 一 & $0-2 \cdot 5$ & - \\
\hline Pasteurized... & 66 & $87 \cdot 6$ & $3 \cdot 3$ & $3 \cdot 6$ & $4 \cdot 7$ & $0 \cdot 120$ & $70-200$ & None & $|0 \cdot 5-3 \cdot 0|$ & None & 11 & $10 \%$ & $0 \cdot 1-0.2$ & None & $0-2 \cdot 0$ & $20 \%$ \\
\hline $\begin{array}{l}\text { Sterilized } \\
\text { Spray dried }\end{array}$ & 66 & $87 \cdot 6$ & $3 \cdot 3$ & $3 \cdot 6$ & $4 \cdot 7$ & $0 \cdot 120$ & $70-200$ & None & $0 \cdot 5-3 \cdot 0$ & None & 8 & $30 \%$ & $0 \cdot 1 \multimap 0 \cdot 2$ & None & $0-1 \cdot 2$ & $50 \%$ \\
\hline $\begin{array}{l}\text { whole } \\
\text { Roller dried }\end{array}$ & 512 & $3 \cdot 0$ & $25 \cdot 0$ & $27 \cdot 5$ & $37 \cdot 5$ & 0.910 & $550-1600$ & None & $3 \cdot 9-23$ & None & 85 & $10 \%$ & $0 \cdot 8-1 \cdot 6$ & None & $0-16$ & $20 \%$ \\
\hline whole $\cdots$ & 512 & $3 \cdot 0$ & $25 \cdot 0$ & $27 \cdot 5$ & $37 \cdot 5$ & 0.910 & $550-1600$ & None & $3 \cdot 9-23$ & None & 80 & $15 \%$ & $0 \cdot 8$ & None & $0-13$ & $30 \%$ \\
\hline $\begin{array}{l}\text { Dried skim ... } \\
\text { Condensed }\end{array}$ & 357 & $4 \cdot 0$ & $36 \cdot 0$ & $0 \cdot 5$ & 50, & $1 \cdot 250$ & Trace & Most & Nor & (1) & 115 & $10 \%$ & $1 \cdot 2$ & None & $0-20$ & $30 \%$ \\
\hline whole - & 169 & $68 \cdot 5$ & $8 \cdot 4$ & $9 \cdot 2$ & $12 \cdot 0$ & $0 \cdot 300$ & $180-500$ & None & $1 \cdot 3-7 \cdot 6$ & None & 18 & $40 \%$ & $0 \cdot 25-0.5$ & None & $0-2 \cdot 5$ & $60 \%$ \\
\hline $\begin{array}{l}\text { unsweetened } \\
\text { (evaporated) }\end{array}$ & 144 & $73 \cdot 0$ & $7 \cdot 0$ & $8 \cdot 0$ & $10 \cdot 0$ & $0 \cdot 260$ & $150-430$ & None & $1 \cdot 1-6 \cdot 5$ & None & 16 & $40 \%$ & $0 \cdot 22-0 \cdot 44$ & None & $0-2 \cdot 2$ & $60 \%$ \\
\hline $\begin{array}{c}\text { Condensed } \\
\text { whole- }\end{array}$ & & & & & & & & & & & & & & & & \\
\hline sweetened ... & 344 & $25 \cdot 0$ & $8 \cdot 8$ & $9 \cdot 5$ & $53 \cdot 5$ & $0 \cdot 325$ & $190-530$ & None & $\mid 1 \cdot 4-8 \cdot 1$ & None & 29 & $10 \%$ & $0 \cdot 27-0 \cdot 54$ & None & $0-5 \cdot 7$ & $15 \%$ \\
\hline
\end{tabular}

The composition varies from sample to sample; the figures given in the table may be taken as representative.

? Varies according to season.

3 Varies according to the handling of the liquid milk.

4 Product hitherto made in Great Britain in accordance with 1923 Condensed Milk Regulations.

- Suggested composition for product manufactured in accordance with the recently reduced standards (Condensed Milk Order, 1940) and corresponding with U.S.A. Standards.

A brief account of the relative nutritive properties of milk in its different forms may hence be timely.

It should be realized at the outset that, from the point of view of nutritive value, milk is a variable food. Though its 'major' constituents, protein, fat, carbohydrate and ash, change but little throughout the year, some of its vitamins are subject to marked fluctuations according to the season and the nutrition of the cow. Unless this is understood, any comparison of separate types of milk of different origin would be clearly misleading, especially as concentrated forms of milk are manufacted mostly in summer and early autumn.

The importance of milk in human nutrition rests primarily on its content of first-class animal protein of high biological value, its exceptional richness in calcium, and its valuable contribution of vitamin $A$ and of riboflavin and other water-soluble vitamins. It is generally agreed that even in peacetime, when all foods are plentiful, it is difficult to plan an adequate diet without the use of milk or much less drastic than was formerly believed. The idea that raw cow's milk possesses unique nutritive properties which are lost if it is exposed to any form of heat treatment is certainly not supported by the bulk of modern evidence. Losses undoubtedly occur ; some are avoidable and should be prevented, others can be made good by intelligent planning of the diet.

Of the milk constituents the proteins and certain vitamins are most liable to heat injury and the extent to which this takes place can best be judged by taking raw fresh liquid milk as a base line. Typical analytical figures are given in the accompanying table, and little comment is needed on the 'major' constituents. It is probably superfluous to remind the reader that the quantity of fat varies. markedly according to breed, and that the Channel Island breeds produce milk especially rich in this respect. The proteins of milk consist of casein, lactalbumin and lactoglobulin, which are almost completely digestible, and have a high biological 
value, that is, they can be efficiently utilized to build or replace body protein. As judged by animal experiments, this efficiency may reach some 90 per cent for raw milk.

Regarding the so-called 'minor' (on a weight basis) constituents, milk is a rich source of vitamin A, which is partly present as the provitamin, $\beta$-carotene. It is well known that milk produced on pasture is much yellower and also contains more vitamin A than milk of stall-fed cows. Under south of England conditions milk is high in vifamin A from May until November or December, when it contains some 150-200 I.U. per $100 \mathrm{ml}$., and low during the rest of the year, when the concentration drops to about half this quantity. Vitamin D, of which there is little in milk, also varies with the season, but normally it depends not on the feed, but on the direct action of the sun on the cow. There is a steep peak, therefore, around the summer solstice, which drops away sharply on either side. In May, June, July and August there are about 2.5 r.U. of vitamin D in $100 \mathrm{ml}$. of milk; during the rest of the year the content falls to one half to one fourth or even less of this figure.

Of the water-soluble vitamins riboflavin is richly represented in milk, which contains some $100 \mu \mathrm{gm}$. per $100 \mathrm{ml}$. during the stall-feeding period, and 150-200 $\mu \mathrm{gm}$. when the cows are on pasture.

The vitamin $\mathrm{C}$ content of milk varies but little throughout the year, and is independent of the feed of the cow. The amount present in milk as it leaves the udder is appreciable; $2 \cdot 0-2 \cdot 5 \mathrm{mgm}$. (40-50 I.J.) per $100 \mathrm{ml}$.; one pint of such milk would supply one quarter to one third of the daily requirements of a child. Vitamin $\mathrm{C}$ is, however, easily destroyed in milk by exposure to light ; it is at first converted into a labile form, dehydroascorbic acid, which in turn decomposes spontaneously or under the action of heat. For this reason commercial milk generally contains only a fraction of the vitamin $\mathrm{C}$ originally present. In any event, care should be exercised not to expose bottled milk unnecessarily to bright light.

The level of vitamin $B_{1}$ in milk is also independent of the feed, and remains constant during the year at about 12-15 I.U. per $100 \mathrm{ml}$.

Several other vitamins belonging to the vitamin B complex are also. present in milk. Some of them, like nicotinic acid and vitamin $B_{6}$ are heat-stable, and are not likely to be affected by processing ; the fate of others has not yet been sufficiently studied.

Milk should not be consumed raw unless it is established that it is bacteriologically safe. Rapidly brought to the boil to ensure freedom from infection, it loses little or nothing of its nutritive properties. A large part of the commercial supply of milk in Great Britain is now pasteurized by the holder method. It has been satisfactorily established that the only nutritive effects of this treatment are a loss of some 20 per cent in the vitamin $\mathrm{C}$ content (and this due, rather, to previous exposure to light than to heating in the course of pasteurization), and a 10 per cent decrease in the vitamin $B_{1}$ value.

In certain towns in the Midlands, such as Bir mingham, and also in London, there is a demand for yet another form of liquid milk-sterilized milk. Though there is no legal definition of what sterilized milk is, it is customary to apply this term to milk which has been heated to at least $212^{\circ} \mathrm{F}$. (and generally higher) for varying lengths of time. This product, usually sold in swing-stoppered bottles, has the advantage of keeping for long periods of time, and is also liked because of its 'richer' taste. Before the War it was being increasingly used in infant feeding. The drastic heat treatment to which the milk is exposed in the process of sterilization brings about a loss of some 50 per cent of the vitamin $\mathrm{C}$ and of about 30 per cent of the vitamin $B_{1}$ originally present. The biological value of the proteins is also slightly decreased-by about 6 per cent. There is no evidence of nutritive impairment of other constituents. Sterilized milk remains, therefore, a most valuable foodstuff, though it is not the equivalent of raw or pasteurized milk, and its shortcomings for infants and children must be recognized and repaired by the addition of necessary supplements.

The stable, concentrated forms of milk are, broadly speaking, prepared in three different ways. The moisture may be removed as completely as possible, giving dried milk powder; or it is only partly removed, and the condensed milk is either sterilized by heat treatment to ensure bacteriological purity or enough sugar is added in the process of manufacture to inhibit bacterial growth. All three methods in various modifications are applied to separated as well as to full-cream milk. Most of the 'major' and some of the important 'minor' constituents of milk are relatively stable, and these are not affected by the various commercial processes. Thus, vitamin A and carotene, vitamin $D$ and riboflavin survive the various methods of preservation of milk without appreciable loss. Other more labile factors suffer to a greater or lesser extent, according to the severity of the treatments.

Of these treatments drying by modern methods is generally quite mild in its effects. Spray-drying consists in principle in forcing an exceedingly fine spray of milk into a heated chamber, where it dries almost instantaneously. Spray-dried milk is nearly completely soluble in water, and 'reconstitutes' readily. In drying, it loses about 20 per cent of the vitamin $\mathrm{C}$ present in the raw milk and one tenth of the vitamin $B_{1}$. The proteins are only 
very slightly affected, and the 'biological value' is decreased by probably not more than 5 per cent. The significance of such loss may be trivial, as in a mixed diet the various proteins supplement each other, and the biological value of the mixture need not necessarily change. The availability of the minerals of milk, and especially of the valuable calcium it contains, is not affected by the heat treatment. It is clear, therefore, that spray-dried milk retains to a remarkable extent the nutritive qualities of the fresh product.

Another method of drying consists in rapidly dehydrating a thin film of milk on steam-heated revolving metal cylinders, from which it is removed by means of a stationary scraper. First-quality roller-dried milk is, from a nutritional point of view, only slightly inferior to the best spray-dried product, though its solubility in water is generally lower. As a rule, the loss in vitamin $\mathrm{C}$ is slightly higher, nearer 30 per cent, and the deterioration of the proteins is rather more noticeable. In some less satisfactory samples up to one third of the vitamin $B_{1}$ may be lost. Occasionally spray- or roller-dried milk is encountered in which the losses in vitamin $\mathrm{C}$ are much more severe than those just quoted. This is largely due to the practice obtaining in some factories of mixing the bulked milk before drying by bubbling air through it. Fulldream dried milks keep quite well when properly packed in hermetically sealed containers. They ceteriorate, however, on exposure to the air.

Cream has proverbially been considered as the most valuable part of milk, and milk from which the fat had been removed has borne a stigma of inferiority. Even now, when the full food value of milk is much better understood, there is still widespread prejudice against the use of skim milk in human nutrition. In the liquid state it was seldom used for this purpose in Great Britain before the War. Dried, it went into consumption concealed in bakery goods, ice cream, confectioneries and breakfast cereals. Even in the United States, where its use as human food is much more widespread than in Great Britain, some 40 per cent of the dry skim milk was used as animal fodder. Yet, when its limitations are properly understood, it is a most valuable food. The absence of fat and of vitamins $\mathrm{A}$ and $\mathrm{D}$ make it totally unsuitable as a food for babies, and in Great Britain it must be clearly labelled to this effect. All the other important constituents of milk remain, however, unimpaired, and for that matter, proportionally increased at the expense of the missing fat. The high content of animal protein, calcium and riboflavin makes skim milk a most valuable addition to war-time dietaries. Vitamin $\mathrm{C}$ and vitamin $\mathrm{B}_{1}$ are higher than in full-cream milk, and the important, though less well-defined other members of the vitamin B complex are also there in relatively increased amounts. If protected from moisture, dried skim milk keeps almost indefinitely and without need for special packing. Relative cheapness and ease of transport emphasize its value in war-time, and it is to be hoped that as much of it as possible will be made available for general consumption.

Of the milk products from which water is only partly removed, unsweetened condensed milk, generally known as evaporated, is exposed to the more drastic heat treatment. The concentration itself is carried out in vacuo at low temperature, but the milk is then placed in tins which are sealed and sterilized by heat at a temperature of $240^{\circ} \mathrm{F}$. This exerts noticeable effects on the more labile components. Some 60 per cent of the vitamin $\mathrm{C}$, and 30-50 per cent of the vitamin $B_{1}$, are lost. The digestibility and biological value of the proteins decrease slightly but unmistakably. Other factors, so far as is known, remain unimpaired, and the good record of evaporated milk in the feeding of infants and children shows that when its known defects are remedied it remains a food of outstanding value.

Sweetened condensed milk is not exposed to temperatures above the boiling-point of water, and frequently the maximum temperature is well below this. Sugar, which is added before condensing, reaches a final concentration of about 40 per cent and effectively prevents the growth of microorganisms. In up-to-date sweetened condensed milk the losses of nutrients are quite small. Thus, a good specimen may contain only 15 per cent less vitamin $C$, and $5-10$ per cent less vitamin $B_{1}$ than were originally present in an equivalent quantity of the fresh milk before manufacture.

In assessing the food value of different types of milk it should be remembered that dried milks are concentrated about $7 \frac{1}{2}-7 \frac{3}{4}$ times in comparison with fresh milk, and unsweetened condensed milk about $2 \frac{3}{4}$ times. Hence, the amount of milk solids varies in the different products, but the composition of these "solids remains the same. It is altered, however, in sweetened condensed milk by the presence of large amounts of sugar, and this type of milk is richer in total solids than evaporated (unsweetened condensed) milk, though the concentration of the milk solids is roughly the same in both. Such assessments show that the alternative forms of milk which may be offered to the adult population will be perfectly satisfactory from a nutritional point of view, even though their use may entail some readjustment of established food habits. The essential point is to ensure the maximum possible supply of milk in any form for adults, and to reserve a full quota of liquid milk for children and expectant and lactating mothers. 